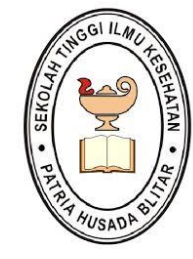

JCSH

JOURNAL OF COMMUNITY SERVICE

FOR HEALTH

http://juda.phb.ac.id/index.php/jcsh

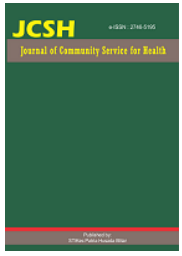

\title{
The Training of Developmental Stimulation on Children with Autism Syndrome Disorder in Autism Center of Blitar City
}

\author{
Suprajitno $^{1}$, Arif Mulyadi ${ }^{2}$, Rachmi Aidah $^{3}$ \\ ${ }^{1,2}$ Nursing Department, Poltekkes Kemenkes Malang, Indonesia \\ ${ }^{3}$ Autism Center of Blitar City, Indonesia
}

\begin{tabular}{|c|c|}
\hline Article Information & Abstract \\
\hline $\begin{array}{l}\text { History Article: } \\
\text { Received, 04/08/2020 } \\
\text { Accepted, 05/09/2020 } \\
\text { Published, 05/11/2020 }\end{array}$ & $\begin{array}{l}\text { Children with Autism Syndrome Disorder (ASD) have the same developmental } \\
\text { tasks and must be stimulated from an early age. Stimulation can be performed } \\
\text { by parents or caregivers. This community service aimed to provide parents or } \\
\text { caregivers with the ability to stimulate the development of children with ASD. }\end{array}$ \\
\hline $\begin{array}{l}\text { Keywords: } \\
\text { Autism Syndrome } \\
\text { Disorder, Development, } \\
\text { Stimulation }\end{array}$ & $\begin{array}{l}\text { Autistic Children's Activity Guide at Home: A Guide for Parents (Buku Bina } \\
\text { Aktivitas Anak Autis di Rumah: Panduan Bagi Orang Tua) ISBN: 978-602- } \\
\text { 6397-32-4. Training conducted twice by therapists in Autism Center of Blitar } \\
\text { City. The training evaluation used a checklist consisting of } 17 \text { abilities. The } \\
\text { changes were known from the mean increase in ability of } 15.4 \text { and the standard } \\
\text { deviation decreased to } 7.94 \text {. After the training, there was a change in the ability } \\
\text { to perform developmental stimulation of children with ASD and parents or } \\
\text { caregivers said they were very satisfied because they had the guidelines to be } \\
\text { used at home. }\end{array}$ \\
\hline
\end{tabular}

(C) 2020 Journal of Community Service for Health

\footnotetext{
Correspondence Address:
}

Poltekkes Kemenkes Malang - East Java, Indonesia

E-ISSN : 2746-5195

Email: suprajitno_skp@poltekkes-malang.ac.id

DOI: https://doi.org/10.26699/jcsh.v1i1.ART.p026-032

This is an Open Access article under the CC BY-SA license (http://creativecommons.org/licenses/by-sa/4.0/) 


\section{INTRODUCTION}

Children with ASD as future successor individuals are expected to be independence. Children with ASD also have the task of growth and development based on the age which must be stimulated from an early age (Brooks, 2011; Suprajitno, 2004). The developmental tasks of children with ASD include gross motor skills, fine motor skills, language, and socialization. In order to optimize the development, stimulation is needed especially by parents or caregivers who are always close to them. Children with ASD also need to be stimulated from an early age or after being detected with ASD so that they could have optimal development based on their age (Suprajitno \& Aidah, 2017).

The developmental stimulation can be done well by parents or caregivers when they already have knowledge and skills. Knowledge and skills can be acquired on their own or trained by others (Notoatmodjo, 2003). In order to increase their knowledge and skills, community service activities are carried out through training activities. Training is a conscious effort through planned activities to help improving the abilities of parents or caregivers as expected. The training aims to improve the ability of parents or caregivers of children with autism to be able to perform early stimulation. The reason of the training for parents or caregivers of children with autism who receive services at the Autism Center of Blitar City is that parents do not realize that their children are in the special needs category, do not know what to do to meet children's needs, and do not have the ability to stimulate children at home.

The purpose of the community service activities carried out by Poltekkes Kemenkes Malang was parents or caregivers of children with autism have knowledge and can stimulate their children at home. The benefits of the training activities were parents or caregivers could perform good stimulation so that children with autism can grow and develop optimally based on their age.

\section{METHODS}

The community service activities used a training approach, independent stimulation, and evaluation. The training was conducted twice in small groups of parents or caregivers by the therapists at the Blitar City Autism Service Center. The self-stimulation was carried out by caregivers at home to children with ASD. The evaluation was carried out by the therapist at home.

The training material was the Book of Autistic Children's Activity Guide at Home: A Guide for Parents (Buku Bina Aktivitas Anak Autis di Rumah: Panduan Bagi Orang Tua) 
ISBN: 978-602-6397-32-4. The training participants were 40 parents or caregivers of children with ASD at home. There were four therapists, namely (1) Theophilus Rendy K, S.Psi., (2) Valentino Nova D., S.Pd., (3) Liasari, and (4) Retno Wulandari, A.Md.Pust. The training were done on June 15, June 16, June 29, June 30, July 13, and July 152020 between 09.00 - 12.30 WIB. The evaluation of the ability of parents or caregivers to perform stimulation was done on June 18, July 3, and July 17, 2020. The evaluation of the abilities used an observation checklist containing 17 abilities categorized as Cannot, Need Help, Can, or Skillfull.

\section{THE IMPLEMENTATION OF THE ACTIVITY}

The training activity was begun on June 15, 2020 attended by the Head of PLA Blitar City, the Head of the Health Unit at the Kepanjen Kidul Health Center, Blitar City, Team of community services, Therapists, and parents or caregivers of children with ASD.
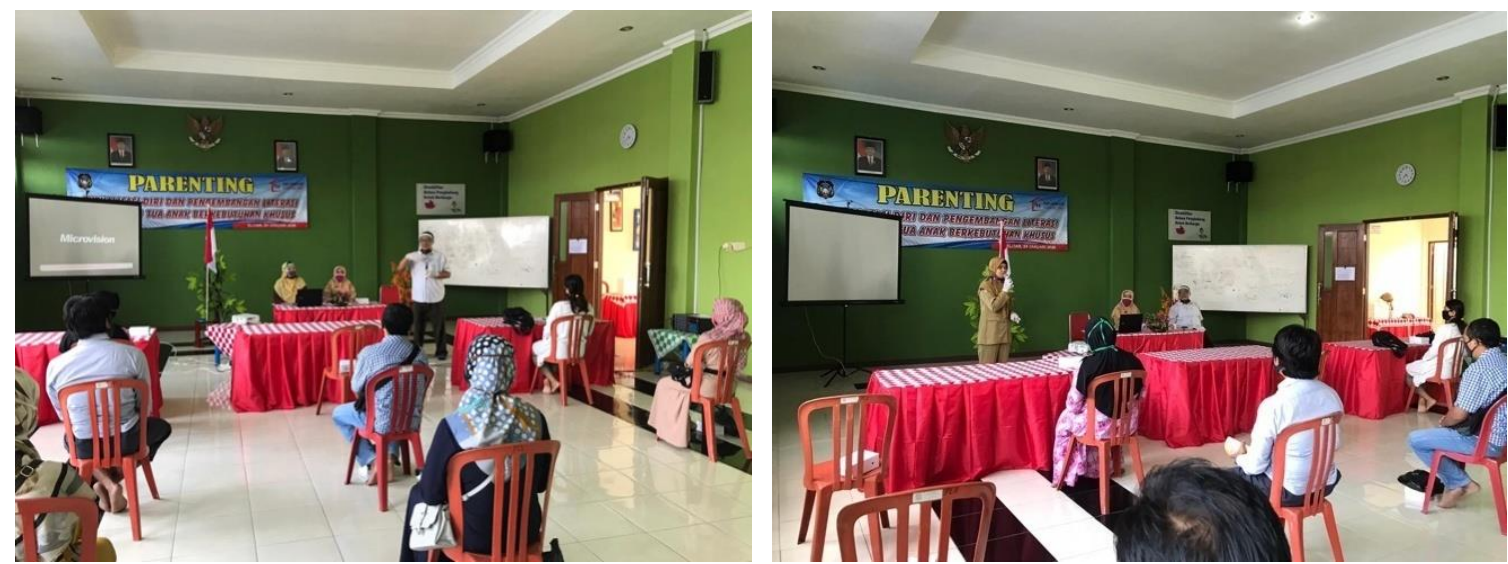

The training activities during the COVID-19 pandemic began with risk screening based on the advice of the Blitar City COVID-19 Response Acceleration Task Force. The training of developmental stimulation was as shown in the following picture:

(1) Performing health protocol before entering Blitar City Autism Center

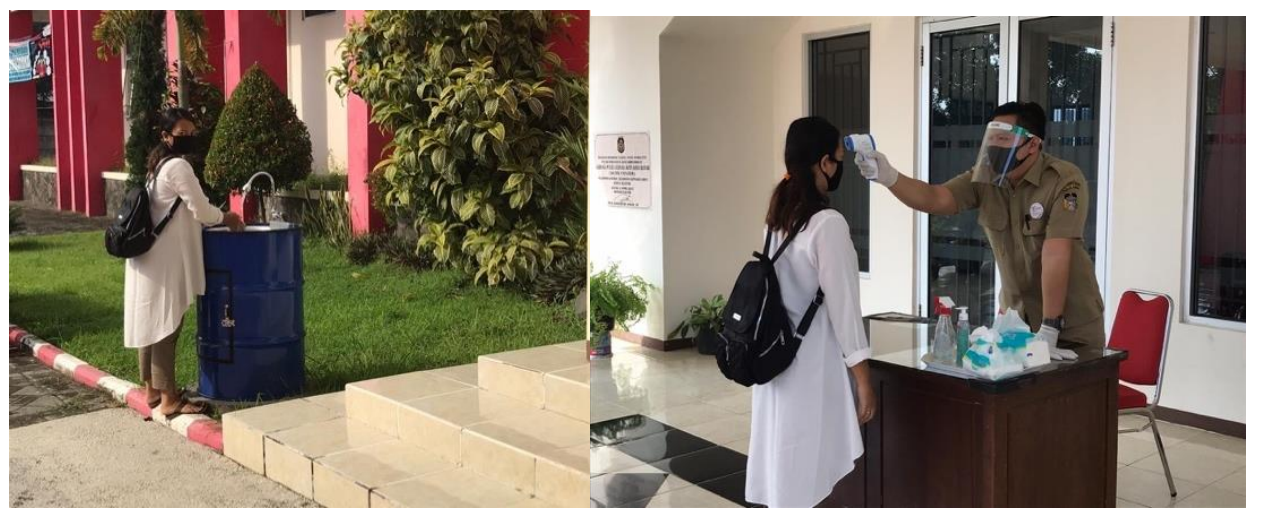


(2) Training of washing hands with soap and running water to the children with ASD.

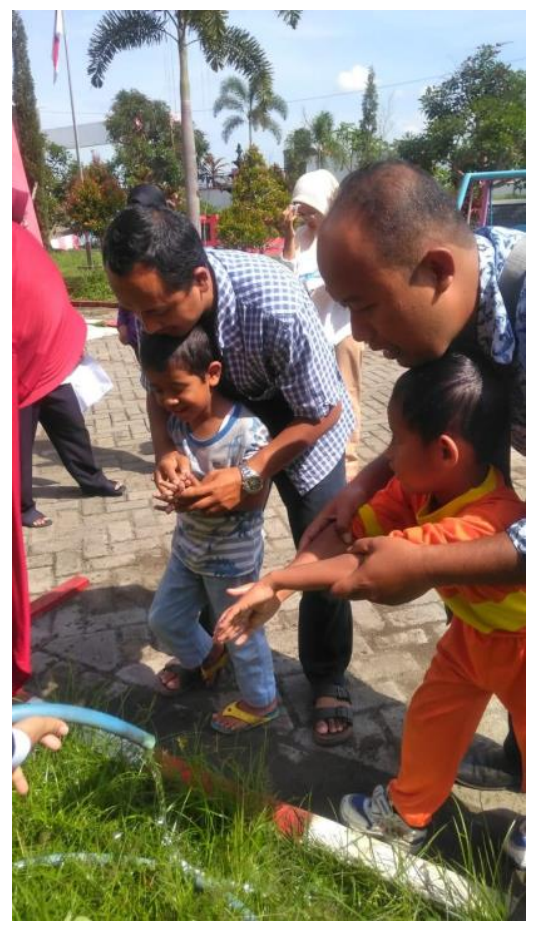

(3) The training activities were carried out in the front hall of the Blitar City Autism Center.
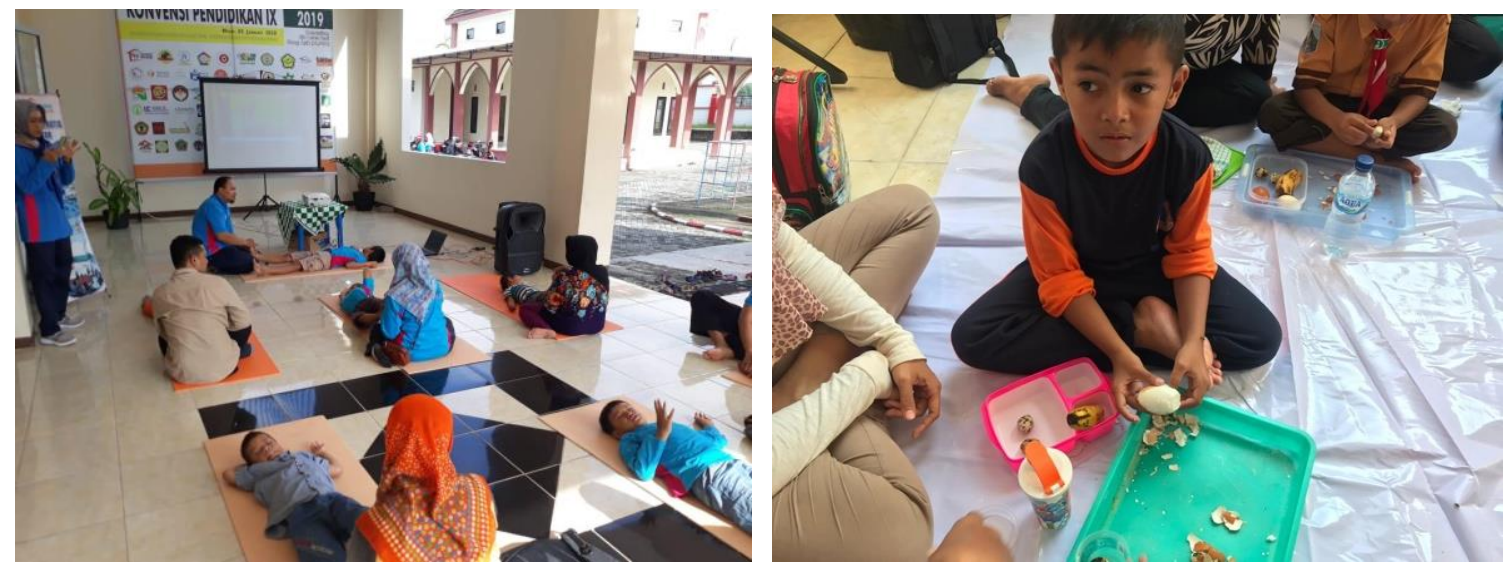

During the COVID-19 pandemic, the training was carried out at the front of the Blitar City Autism Center which aimed to make the environment of training activities exposed by free air so that the risk of COVID-19 transmission could be reduced.

(4) The profile picture of the children with autism in Blitar City Autism Center which already capable to attend inclusive education of elementary school level. 


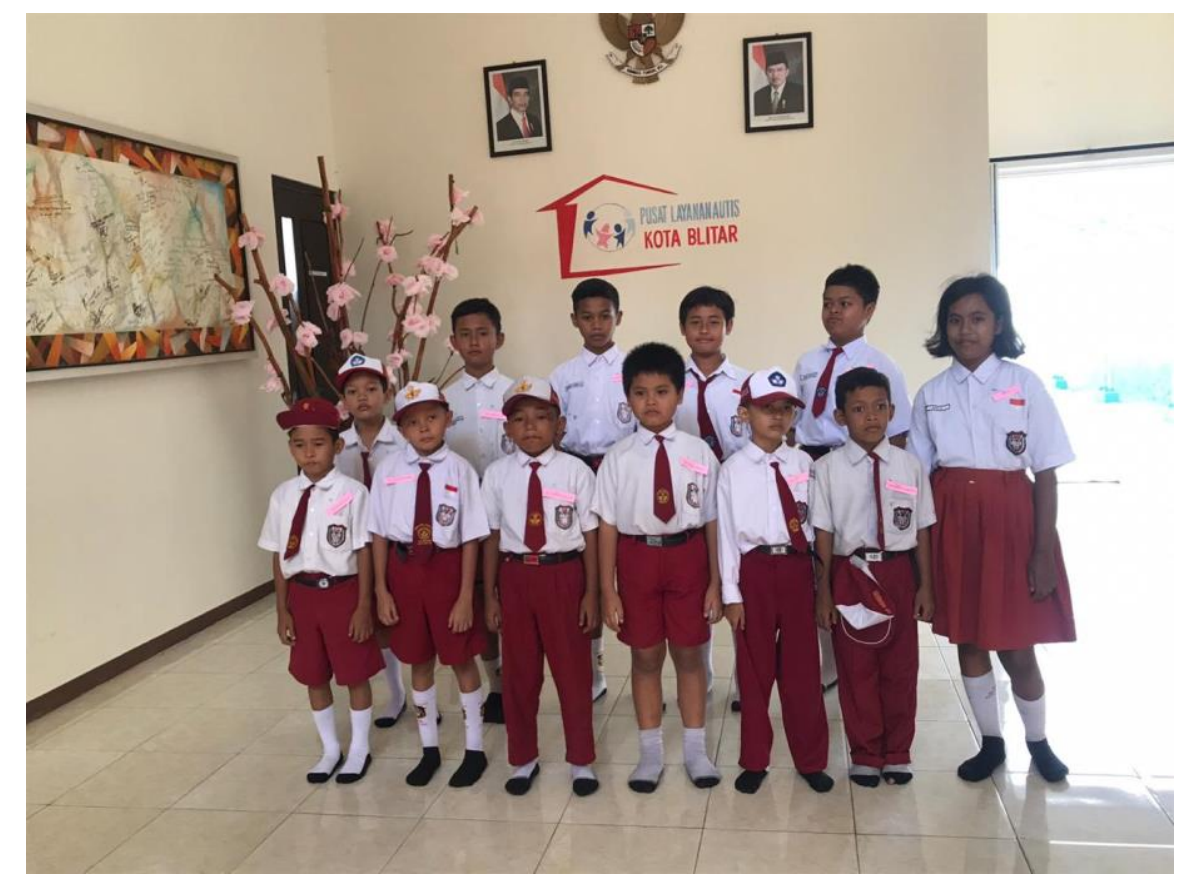

\section{RESULTS}

The characteristics of parents and children with autism who received services in Blitar City Autism Center were shown in Table 1.

Table 1 The characteristics of parents and children with autism who received services in Blitar City Autism Center on the training activity on June - July 2020

\begin{tabular}{|c|l|c|c|c|r|}
\hline No. & \multicolumn{1}{|c|}{ Characteristic } & Minimum & Maximum & $\mathrm{f}$ & \multicolumn{1}{c|}{$\%$} \\
\hline 1 & Age of the parents (years old) & 28 & 56 & & \\
\hline 2 & Age of the children with autism & 2 & 11 & & \\
\hline 3 & Address: & & & & \\
& $-\quad$ Kota Blitar & & & 15 & 37,5 \\
& $-\quad$ Kab. Blitar & & & 17 & 42,5 \\
& $-\quad$ Kab. Kediri & & & 7 & 2,5 \\
& $-\quad$ Kab. Tulungagung & & & 17,5 \\
\hline 4 & Birth order... & & & 19 & 47,5 \\
& -1 & & & 12 & 30,0 \\
& $-\quad 2$ & & & 1 & 20,0 \\
& -3 & & & 7 & 2,5 \\
\hline 5 & $-\quad 4$ & & & 23 & 17,5 \\
& Number of siblings: & & 87,5 \\
& $-\quad$ single & & & 20,0 \\
& $-\quad 2$ & & & 1 & 2,5 \\
& -3 & & & & 2,5 \\
\hline
\end{tabular}

There were some reasons that increase the need of children with autism to get services in Blitar City Autism Center such as children who experience speech delay, difficult to concentrate, difficult to communicate, had different behavior than their peers, and did not 
independent. After receiving services at Blitar City Autism Center, the parents expected that the children can be independent, speak immediately based on their age, and receive special education. The ability of the parents in doing developmental stimulation that had been trained and measured included (1) Crawling under a cloth tunnel, (2) Playing faces in front of a mirror, (3) Touching and holding round or angular objects, (4) Coloring pictures using dyes, (5) Singing according to the child's preference or age, (6) Lending toys that the their friends like, (7) Following orders given by children or other people, (8) Inviting other children to play the same, (9) Mimicking or modifying other children's movements, (10) Providing simple reading materials, (11) Providing simple counting materials, (12) Asking the children to write people's names parents and siblings, (13) Asking the children to write names of playmates or those who know them, (14) Asking the children to write good free sentences, (15) Asking the children to sing children's songs, (16) Asking the children to imitate songs they are listening to, and (17) Asking the children to concentrate on watching television shows.

The ability of the parents or caregivers of children with ASD to do developmental stimulation were shown in Table 2.

Table 2 The ability of the parents of children with ASD who received service in Blitar City Autism Center to do developmental stimulation on the training activity on June-July 2020

\begin{tabular}{|c|l|c|c|c|}
\hline \multirow{2}{*}{ No. } & \multirow{2}{*}{ Value } & \multicolumn{3}{|c|}{ Training Activity } \\
\cline { 3 - 5 } & & Before & After & Change \\
\hline 1 & The lowest & 17 & 33 & 0 \\
\hline 2 & The highest & 51 & 63 & 31 \\
\hline 3 & Average & 32,2 & 47,2 & 15,4 \\
\hline 4 & Standard Deviation & 9,21 & 8,74 & 7,98 \\
\hline
\end{tabular}

Based on the results of the interviews about the satisfaction of the training activities, most of the parents said they were satisfied and very satisfied with the argument that they received a guidebook that could be studied and used as material to train their children at home since the education process in Blitar City Autism Center was not carried out every day. Several reasons supported the argumentation of the satisfaction such as (1) Education conducted by Blitar City Autism Center was carried out once a week on the specified day and time; (2) During the COVID-19 pandemic, every student was not allowed to come to Blitar City Autism Center but parents were given the opportunity to report and consult on the development of their children at home every two weeks; and (3) Blitar City Autism Center did not provide written guidance that made it possible after being trained and arrived home parents forgetting what they had to do. Other benefits obtained by the families or parents 
after being given the guidance and training to do stimulation were that families had the same perception based on the guidelines. The stimulation could be done by individuals who had not received the training by following the written guidance or manuals as learning material to do the stimulation.

The Blitar City Autism Center manager expected that this community service can be continued every year with not only for 40 parents but to all of the parents of the students. The reason is that the number of students in 2020 will be increased to 80 people, which is possible to increase continually in the following year. In 2021 the organization will change the name into Disability Service Center allows it to be used as a place of community service with variety of targets.

\section{CONCLUSION}

Based on the results of the evaluation in community service activities, it was concluded that there was a change in the ability of the parents to do developmental stimulation to the children with ASD at home. Parents or caregivers were very satisfied because they had written guidelines that could be used to train their children at home.

\section{SUGGESTION}

Thanks for to the Director of Poltekkes Kemenkes Malang, Blitar City COVIS-19 Response Acceleration Task Force, and Blitar City Autism Service Center for the guidance and supports so that this community service can run successfully.

\section{REFERENCE}

Brooks, Jane. (2011). The Process of Parenting. Yogyakarta: Pustaka Pelajar.

Notoatmodjo, Soekidjo. (2003). Promosi Kesehatan dan Perilaku Kesehatan. Jakarta: Rineka Cipta.

Suprajitno. (2004). Asuhan Keperawatan Keluarga: Aplikasi dalam Praktik. Jakarta: EGC.

Suprajitno \& Aidah, Rahmi. (2017). Bina Aktivitas Anak Autis di Rumah: Panduan Bagi Orang Tua. Malang: MNC Publishing. 